ПУБЛІЧНЕ УПРАВЛІННЯ ТА АДМІНІСТРУВАННЯ

УДК 366.02

https://doi.org/10.35546/kntu2078-4481.2021.3.12

O.O. BORZENKO

Institute of economy and forecasting NAS Ukraine ORCID: 0000-0002-1017-5942

\title{
FOREIGN EXPERIENCE OF FINANCIAL SECURITY OF LOCAL GOVERNMENT IN THE CONDITIONS OF BUDGET DECENTRALIZATION
}

The article examines the foreign experience of financial support of local government in terms of budget decentralization.

Continuation of negative phenomena in the economy, which results in a deficit of budget resources, requires a constant search for sources of replenishment of local budgets and the introduction of new approaches to the management of financial resources at the state and local levels. The theoretical and practical aspects of the formation and use of financial resources of local budgets, the development of financial decentralization is devoted to the work of such domestic researchers as S. Dyachenko, J. Kazyuk, O. Kyrylenko, I. Lunina, N. Melnychuk, S. Romanyuk, V. Oparin, V. Fedosov, S. Yuri and others. However, despite the significant number of publications on the outlined problems, many issues related to the management of financial resources of local budgets in the context of decentralization remain insufficiently studied.

The purpose of the study is to analyze the processes of financial resources management of local budgets in the context of decentralization and to develop practical recommendations for the management of local budget resources.

In the context of budget decentralization, the foreign experience of financial support of local selfgovernment, which is presented in the form of Scandinavian, Latin and Hanoverian models, deserves attention. Adaptation of foreign experience of financial support of local self-government in the conditions of budget decentralization will help to solve the set problems competently.

Key words: decentralization, local budgets, foreign experience, deficit, financial resources.

О.О.БОРЗЕНКО

Інститут економіки та прогнозування НАН України ORCID:0000-0002-1017-5942

\section{ЗАРУБІЖНИЙ ДОСВІД ФІНАНСОВОГО ЗАБЕЗПЕЧЕННЯ МІСЦЕВОГО САМОВРЯДУВАННЯ В УМОВАХ БЮДЖЕТНОЇ ДЕЦЕНТРАЛІЗАЦЇ̈}

У статті досліджується зарубіжний досвід фінансового забезпечення місцевого самоврядування в умовах бюджетної децентралізації.

Продовження негативних явищ в економіці, щзо має наслідком дефіuчит бюджетних ресурсів, вимагають постійного пошуку джерел поповнення місиевих бюджетів та запровадження новітніх підходів до управління фінансовими ресурсами на державному та місиевому рівнях. Теоретичним $i$ практичним аспектам формування й використання фінансових ресурсів місиевих бюджетів, розвитку фінансової децентралізації присвячено праџі таких вітчизняних дослідників як С. Дяченко, Я. Казюк, О. Кириленко, І. Луніна, Н. Мельничук, С. Романюк, В. Опарін, В. Федосова, С. Юрія та інші. Проте, незважаючи на значну кількість публікацій з окреслених проблем, багато питань, щуо стосуються управління фінансовими ресурсами місцевих бюджетів в умовах децентралізації, залишаються недостатньо вивченими.

Мета дослідження полягає в проведенні аналізу процесів управління фінансовими ресурсами місиевих бюджетів в умовах децентралізаџії та розробці практичних рекомендаџій щуодо напрямків управління місиевими бюджетними ресурсами.

В умовах бюджетної децентралізації заслуговуе на увагу зарубіжний досвід фінансового забезпечення місиевого самоврядування, який представлено у вигляді скандинавської, латинської та ганноверської моделей. Адаптація зарубіжного досвіду фінансового забезпечення місиевого самоврядування в умовах бюджетної децентралізаиії допоможе грамотному виріменню поставлених проблем.

Ключові слова: децентралізація, місцеві бюджети, зарубіжний досвід, дефіщит, фінансові ресурси. 


\section{Е.А.БОРЗЕНКО}

Институт экономики и прогнозирования НАН Украины

ORCID:0000-0002-1017-5942

\section{ЗАРУБЕЖНЫЙ ОПЫТ ФИНАНСОВОГО ОБЕСПЕЧЕНИЯ МЕСТНОГО САМОУПРАВЛЕНИЯ В УСЛОВИЯХ БЮДЖЕТНОЙ ДЕЦЕНТРАЛИЗАЦИИ}

В статье исследуется зарубежный опыт финансового обеспечения местного самоуправления в условиях бюджетной децентрализаиии.

Продолжение негативных явлений в экономике, следствием которых является дефищит бюджетных ресурсов, требуют постоянного поиска источников пополнения местных бюджетов и внедрение новых подходов к управлению финансовыми ресурсами на государственном и местном уровнях. Теоретическим и практическим аспектам формирования и использования финансовых ресурсов местных бюджетов, развития финансовой децентрализаиии посвящены работы таких отечественных исследователей как С. Дяченко, Я. Казюк, А. Кириленко, И. Луниной, Н. Мельничук, С. Романюк, В. Опарина, В. Федосова, С. Юрия и др. Однако, несмотря на значительное количество публикаций по обозначенной проблеме, многие вопросы, касаюшиеся управления финансовыми ресурсами местных бюджетов в условиях децентрализации, остаются недостаточно изученными.

Цель исследования заключается в проведении анализа проиессов управления финансовыми ресурсами местных бюджетов в условиях децентрализации и разработке практических рекомендаиий по направлениям управления местными бюджетными ресурсами.

В условиях бюджетной децентрализации заслужсивает внимания зарубежный опыт финансового обеспечения местного самоуправления, которое представлено в виде скандинавской, латинской и ганноверской моделей. Адаптация зарубежного опыта финансового обеспечения местного самоуправления в условиях бюджетной децентрализации поможет грамотному решению поставленных проблем.

Ключевые слова: децентрализация, местные бюджеты, зарубежный опыт, дефицит, финансовые ресурсы.

\section{Problem Statement}

The experience of developed countries shows that the decentralization of public administration and the creation of an effective system of local self-government is a prerequisite for ensuring the well-being of the people.

Decentralization of the budget system today is one of the key factors in the rational distribution and use of budget funds, as well as high efficiency in the provision of public goods and services. This process takes place not only in federal countries and countries with historically influential positions of local government, but also in countries - new EU members, which see it as a significant constructive potential for their own economies [1, p. 82].

Decentralized management of the budget system is typical of many developed countries. Decentralization involves giving local governments the right to solve a number of tasks at the local level and ensure their implementation with the necessary resources.

\section{Analysis of latest research and publications}

The theoretical and practical aspects of the formation and use of financial resources of local budgets, the development of financial decentralization the works of such domestic researchers are devoted: S. Dyachenko, J. Kazyuk, O. Kyrylenko, I. Lunina, N. Melnychuk, S. Romanyuk, V. Oparin, V. Fedosov, S. Yuri and others. However, despite the significant number of publications on the outlined problems, many issues related to the management of financial resources of local budgets in the context of decentralization remain insufficiently studied.

\section{Goal Setting}

The purpose of the study is to analyze the processes of financial resources management of local budgets in the context of decentralization and to develop practical recommendations for the management of local budget resources.

\section{Presentation of research material}

Considering the foreign experience of generating local budget revenues in the context of decentralization, we note that budget decentralization is recognized by many experts as the most difficult aspect of decentralization of public power. World legal literature reveals the essence of this concept through the prism of three determinants:

- Decentralization in the expenditure sphere - the fact of authorization of local governments the right to dispose of financial resources necessary for their activities, the implementation of its tasks; 
- Decentralization in the field of income - granting local governments the right to receive their own income on a fixed list in an amount (established independently), sufficient for their proper and quality work;

- The right to procedural and organizational independence - the formation, approval, implementation of financial plans, estimates, budgets, reporting and control under the responsibility of a particular body, a local official [2, p. 79].

Budget decentralization (as a process) can be measured quantitatively and qualitatively. The scientific literature has certain methodological, theoretical approaches to the definition of such criteria, among which there are a number of basic ones.

The main indicator of budget decentralization is often considered to be the ratio between local and national expenditures. It testifies to the financial ability of local governments to perform their tasks and functions. In Denmark, Spain, Sweden more than $50 \%$ of all costs are local [2, p. 81].

It is also believed that the progress of budget decentralization in the country is characterized by the share of local budget expenditures in GDP. This indicator determines the part of the public resource that is distributed among the representatives of local self-government. We can say that when the figure is above $15 \%$, then the state has a high level of decentralization. In Europe, such countries are called Denmark, Sweden, Spain, Finland, the Netherlands and Italy. The share of $10-15 \%$ is the average state of decentralization: Poland, Great Britain, Hungary, the Czech Republic and France. Insufficient decentralization still occurs in Slovakia, Lithuania, Estonia, Portugal, Greece, and Cyprus [2].

Financial independence (autonomy) of a local self-government body is assessed as an indicator of the share of own income in the gross income of the territorial community. The rights of a local self-government body to set tax rates and determine the amount of other income can be exercised only in relation to its own income, it is the right to its own income base and its administration. Countries where the share of own income in the gross income of the territorial community is more than 50\% are Sweden, Denmark, Finland, France, Luxembourg, Cyprus, Austria, Belgium, Ireland, Portugal and others [2]. This indicator can be considered not only a quantitative but also a qualitative type of criteria for budget decentralization.

The indicator of the share of equalization subsidies, inter-budget transfers in local budget revenues helps to assess the level of financial autonomy of local self-government bodies. Dependence is inversely proportional: the higher the rate, the lower the autonomy and independence of local governments. Thus, the high rate indicates a weak decentralization, as local governments do not affect the number of intergovernmental transfers [2].

The financial basis of local self-government consists of local budget revenues, ie financial resources of local budgets. It is the revenues of local budgets that can be considered the central link of the financial system of local self-government, and it is through budgetary powers that the financial and legal competence of local selfgovernment bodies is realized. The basis of local budgets' own revenues is tax revenues.

Based on the main criteria for assessing the level of financial decentralization, world practice identifies three models of financial support for local government:

1. Scandinavian model, where local taxes account for $10-20 \%$ of GDP and $20-50 \%$ of all taxes. The countries of this model are Sweden, Denmark and Finland;

2. Latin model, where local taxes make up 4-6\% of GDP and about $20 \%$ of all taxes. These indicators are typical for Italy, France and Spain;

3. Hanoverian model, where local taxes account for $1-2 \%$ of GDP and about $4-5 \%$ of all taxes. This is typical for Germany, Great Britain, the Netherlands, and Poland.

Considering the above models of financial support of local self-government, we will consider the peculiarities of the formation of financial resources of local budgets in the following countries: Finland (Scandinavian model), Spain (Latin model) and Poland (Hanoverian model).

The main tax revenue in Finland is provided by the household income tax. An important feature of the Finnish tax system is the broad rights of municipalities to set rates for labor income and utilities (mainly water, sewerage, electricity) and about $15 \%$ for general central government transfers.

The experience of Finland shows that the growing role of local tax revenues - in contrast to transfers from the central budget - deepens financial disparities between municipalities, as changes in the economic situation affect the dynamics of tax revenues in different ways, especially corporate income tax.

An important role in the formation of revenues of Finnish municipalities is played by the system of their equalization, aimed at reducing the effects of regional differences in tax bases and creating conditions for municipalities to provide the same standards of public services. In the Finnish equalization system, municipal revenues are estimated on the basis of the potential tax revenue per capita, i.e. the revenues that the municipality could collect if the country's average municipal tax rate was applied. For municipalities whose potential per capita tax revenues are below $90 \%$ of the national average, the equalization system compensates for the corresponding difference (up to 90\%). Those municipalities where the level of tax revenues is above $90 \%$ of the average in the country transfer to the equalization system funds in the amount of $40 \%$ of potential tax revenues per capita, which exceed the $90 \%$ threshold. Until 2002, the maximum contribution of the municipality to the 
equalization system did not exceed $15 \%$ of its tax revenues. If the municipality's tax revenues exceeded $144 \%$ of the national average, its contribution to the equalization system was reduced to $15 \%$ of its own tax revenues. In 2002, this upper threshold was abolished, but the withdrawal of tax revenues began to compensate by increasing transfers to social protection and health care. Despite the abolition of this threshold, the Finnish equalization system equalizes local government revenues to a lesser extent than similar systems in Denmark, Norway and Sweden [3, p. 132].

It should also be noted that the system of equalization of local budget revenues in Finland does not have a significant impact on the state of the central budget, as the total amount paid by donor municipalities is approximately equal to the amount received by the recipient municipalities [3, p. 134].

In addition to general transfers, municipalities receive subventions to finance certain social services and health care, which are based on age structure and certain geographical criteria (such as population size and density). Social transfers also depend on the unemployment rate in the region, transfers to health care depend on the level of morbidity, and transfers to education depend on the number of students. Such transfers are reviewed annually to consider the dynamics of prices and wages in the budget sphere. Since 1990, due to a significant increase in tax revenues at the municipal level, the responsibilities of municipalities have been expanded, and the share of transfers in local revenues decreased from $30 \%$ in 1990 to about $15 \%$ in 2000 [3, p. 134].

Consider also the conditions for the formation of revenues of local budgets in Spain (Latin model) in the development of a decentralized budget system. Until 1978, the country had a centralized model of the budget system. In the process of decentralization, both the powers and responsibilities of local authorities at the regional level have been expanded. Local authorities have been empowered to self-determine the rate of real estate tax in cities, as well as to introduce an additional local personal income tax (in the form of a local surcharge on net personal income tax liabilities). However, from the end of 1986 the norm on self-establishment by local authorities of the real estate tax rate in cities was abolished, and restrictions on the amount of additional local surcharge to personal income tax in the form of clearly defined maximum and minimum rates [3, p. 137].

Today, local authorities in Spain pay taxes such as real estate tax, business tax, vehicle tax, which are mandatory, as well as building tax, land growth tax in cities, which can be applied by the authorities local authorities. In all cases, local authorities independently determine the amount of tax rates, but within the limits established by law.

Real estate tax is a key in Spain's local tax system because it provides more than a third of total tax revenue. This tax is levied on rural and urban real estate in villages and towns. Revenues from this source depend on the valuation of real estate and on rising real estate prices (including new homes), which is reflected in local tax registers.

Another mandatory tax that comes to Spain's local budgets is a transport tax, which is levied on the value of cars and other vehicles.

Optional taxes, which also go to the country's local budgets, include building tax and urban land tax. These two taxes form a significant share of financial resources of local budgets in Spain (especially large cities and cities with high rates of economic development) [3, p. 139]. The local budgets of Spain include part of the national taxes, the terms of distribution of which are reviewed every 5 years and take into account changes in nominal GDP. Deductions from national taxes are the main type of transfers to local budgets from the central budget.

Since 2002, the single common transfer system has been replaced by two different systems separately for large and small municipalities. Thus, the total transfers received by municipalities with a population of more than 75,000 inhabitants, as well as administrative centers, provinces, autonomous regional associations, consist of two parts: the share of national taxes (based on the principle of territorial binding) and additional funding.

Poland has a recognized European success story in implementing the principle of decentralization in local government reform. Polish reforms in the field of local self-government and territorial organization of public power originate from the history of the national statehood of Poland, which is largely related not only chronologically but also mentally and geographically to the genesis of the Ukrainian state [4].

The Law "On Revenues of Territorial Self-Government Bodies" identifies three main components of local budget revenues: 1) own revenues, which by law include all revenues of local self-government bodies, except for official transfers received; 2) general transfers; 3) targeted transfers from the state budget. In contrast to communes, counties and voivodships have only revenues from the distribution of national taxes on income of legal entities and individuals, the deduction rate from which has increased significantly since 2002 [3, p. 207 ].

The most significant own revenues of local governments are the personal income tax and real estate tax. In 2014 , they accounted for $19.1 \%$ and $11.5 \%$ of local budget revenues, respectively. Revenues from corporate income tax are also significant $(5.3 \%)$.

Among all bodies of territorial self-government of Poland, only gminas are endowed with powers in the field of taxation. Their tax rights are not very broad and are limited to the introduction of local taxes according to the statutory list, the provision of benefits for their payment and the regulation of tax rates within the established 
limits. These powers extend to own tax revenues, which have a significant fiscal significance, in particular to real estate tax, land tax and tax on vehicle owners, in addition to personal income taxes.

Higher-level territorial self-government bodies (counties and voivodships), as well as rayon and oblast councils in Ukraine, cannot introduce their own taxes or regulate the level of taxation.

Revenues from municipal property play a significant role in the formation of local budgets in Poland: the sale of land and buildings, long-term leases and leasing of communal property. A significant part of such revenues is received by local governments through the lease of the first floors of municipal buildings.

The Polish general purpose transfer system is based on objective indicators and is therefore protected from political manipulation and bureaucratic decisions. The criteria for granting general transfers are relatively stable, which allows local governments to carry out long-term financial planning. From the point of view of ensuring the financial independence of these bodies, it is also positive that the degree of budget equalization is not high enough to deprive them of incentives to develop the local economy and strengthen the revenue base.

An important element of the financial independence of local governments in Poland is the ability to decide for them whether or not to perform optional (optional) tasks. Changes may also waive tax or fees, exercise the right to reduce rates on certain local taxes (in particular, property taxes, vehicles, land and forest taxes), provide benefits and exempt from local taxes. In addition, the legislation gives communes the power to set prices and fees for services in compliance with mandatory criteria and restrictions.

Supervision over the financial activities of the bodies of territorial self-government of Poland by the government administration is carried out by specially created regional clearing houses [5]. Their competence includes detection and rejection of illegal decisions of self-government bodies on financial issues.

\section{Conclusions}

The analysis of processes of management of financial resources of local budgets in the conditions of decentralization has shown that incomes of local budgets are the central link of financial system of local government, and through budgetary powers the financial and legal competence of local governments is realized. Today, the basis of local budgets' own revenues is tax revenues.

In the context of budget decentralization, the foreign experience of financial support of local selfgovernment, which is presented in the form of Scandinavian, Latin and Hanoverian models, deserves attention. The conducted detailed analysis of these models will allow to develop optimal practical recommendations on the areas of local budget resources management and will help to solve the problems competently.

\section{References}

1. Hnydiuk I.V. Detsentralizatsiia biudzhetnoi systemy: dosvid Slovachchyny ta perspektyva dlia Ukrainy [Decentralization of the budget system: the experience of Slovakia and prospects for Ukraine] / I.V. Hnydiuk // Oblik i finansy. 2015. № 3(69). p. 80-87.

2. Demchak R.Ie. Formuvannia modelei biudzhetnoi detsentralizatsii: dosvid zarubizhnykh krain [Formation of models of budget decentralization: experience of foreign countries] / R.Ie Demchak // Ekonomichnyi forum. 2015. № 3. p. 77-83.

3. Lunina I. O., Kyrylenko O. P., Luchka A. V. ta in. Dyversyfikatsiia dokhodiv mistsevykh biudzhetiv [Diversification of local budget revenues]/ Za red. d-ra ekon. nauk I. O. Luninoi; NAN Ukrainy; In-t ekon. ta pro- hnozuv. Kiev, 2010. 320 p.

4. Fedorenko V., Chernezhenko O. Reforma mistsevoho samovriaduvannia ta terytorialnoi orhanizatsii publichnoi vlady v konteksti detsentralizatsii: dosvid Polshchi dlia Ukrainy [Reform of local self-government and territorial organization of public authority in the context of decentralization: the experience of Poland for Ukraine] // Publichne pravo. 2015. № 3(19). p. 103-112.

5. Mrochkovska B. Realizatsiia pryntsypu finansovoi nezalezhnosti v diialnosti gmin [Implementation of the principle of financial independence in the activities of communes] /B. Mrochkovska // Svit finansiv. 2006. № 4. p. 162-163. 